\title{
Una historia en incesante movimiento. La tradición peronista en Trinchera de la Juventud Peronista (1960-1963)
}

\author{
A story in incessant movement. The Peronist tradition in Trinchera de la \\ Juventud Peronista (1960-1963)
}

Andrés N. Funes*

\begin{abstract}
Resumen: El 16 de septiembre de 1955, Juan Domingo Perón era desalojado de la Casa Rosada mediante un golpe de Estado. Con su líder exiliado, el peronismo se enfrentó a lo que podría considerarse su prueba de fuego: resistir tan organizadamente como pueda a los embates "desperonizadores" de los mandos militares, con la esperanza de un pronto regreso de Perón. En este nuevo período, el peronismo comienzó a ser resignificado bajo las presiones del presente; su historia y sus símbolos comenzaron a revestirse de nuevos carices. Aquí la juventud tendrá un lugar primordial. El objetivo de este trabajo es analizar el modo en que fue presentada la tradición peronista en la "Mesa Ejecutiva de la Juventud Peronista de Capital Federal y del Gran Buenos Aires", primer nucleamiento de la Juventud Peronista en los años sesenta, tomando para ello su publicación insignia, Trinchera de la Juventud Peronista (1960 - 1963).
\end{abstract}

Palabras claves: Peronismo, Juventud Peronista, Sesentas, Trinchera, Tradiciones políticas

\begin{abstract}
On September 16, 1955 Juan Domingo Perón was evicted from the Casa Rosada by a coup d'état. With its leader exiled, Peronism faced what could be considered its trial by fire: to resist as organizedly as it was possible the "desperonizadores" attacks of the military commands, in the hope of a soon return of Perón. In this new period, Peronism will begin to be resignified under the pressures of the present; its history and its symbols begin to take on new forms. Here the youth will have a primordial place. The aim of this work will be to analyze the way in which the Peronist tradition was presented in Trinchera de la Juventud Peronista (1960 -1963), a publication of the "Mesa Ejecutiva de la Juventud Peronista de Capital Federal y del Gran Buenos Aires", which was the first organization formed in the sixties.
\end{abstract}

Keywords: Peronism, Peronist Youth, Sixties, Trinchera, Political traditions

Recibido: 27 octubre 2017

Aceptado: 18 diciembre 2017

\footnotetext{
* Argentino. Maestrando en Ciencias Políticas en el Instituto de Altos Estudios Sociales (IDAES) de la Universidad Nacional de San Martín (UNSAM). Becario doctoral Agencia-FONCYT del PICT 3133 "Figuras del pueblo" dirigido por el Dr. Gerardo Aboy Carlés. Mail: andrez_zero@hotmail.com.
} 


\section{Introducción}

Los hombres hacen su propia historia, pero no la hacen a su libre arbitrio, bajo circunstancias elegidas por ellos mismos, sino bajo aquellas circunstancias con que se encuentran directamente, que existen y les han sido legadas por el pasado. La tradición de todas las generaciones muertas oprime como una pesadilla el cerebro de los vivos.

Karl Marx, El 18 Brumario de Luís Bonaparte, 1852.

Este 17 de octubre, de recuerdo a la ilustre compañera desaparecida, es también una lección peronista para todos los argentinos (...) Que esta lección de desprendimiento inicie en la Patria una nueva tradición de grandeza que destruya para siempre lo que pueda quedar en nosotros de materialismo y sordidez.

Juan Domingo Perón, discurso por el 17 de Octubre, 1952.

El 16 de septiembre de 1955, el general Eduardo Lonardi comandó el levantamiento militar que derrocó a Juan Domingo Perón. Tan sólo unos días después, el 23, un Lonardi triunfante asumía la presidencia provisional. Tras 9 años, el peronismo era desalojado del poder y su líder se encontraba con la obligación de escapar de los vencedores para no padecer un funesto destino. Sus huestes, descabezadas y atónitas frente a los sucesos que se venían desarrollando, bien poco pudieron hacer. Para los militares de la "Revolución Libertadora" -como se autodenominó la sublevación triunfante- el derrocamiento del peronismo no debía conducir a señalar "vencedores o vencidos", como el propio Lonardi dejó en claro en su primer discurso en Plaza de Mayo, parafraseando, en este sentido, a otro general: Justo José de Urquiza. Sin embargo, bien pronto las ilusiones de Lonardi se desvanecerían. La asunción del general Pedro Eugenio Aramburu en noviembre del mismo año 55, luego del golpe palaciego a Lonardi, significó un quiebre completo con la apuesta lonardista.

Sin lugar a dudas, la cuestión principal con la que tuvo que liderar el antiperonismo después del golpe fue la de qué hacer con el peronismo. Ante esto, su respuesta fue la puesta en marcha de un proceso de "desperonización". Éste se convirtió en el "signo distintivo y la nueva fuente de conflictos, violencias y frustraciones del gobierno surgido de la 'Revolución libertadora"'. 'A partir del famoso decreto-ley 4161 de marzo de 1956, la desperonización involucró toda una serie de medidas que iban, desde la remoción de los nombres de Perón y de Eva Perón (o Evita) de toda calle, plaza o institución que hubiese

${ }^{1}$ Maria Estela Spinelli, Los vencedores vencidos. El antiperonismo y la Revolución Libertadora, Buenos Aires, Biblos, 2005, 54. 
sido bautizada de ese modo, la prohibición de libros con "contenido peronista" o de la famosa marcha "Los muchachos peronistas", hasta la intervención de la Confederación General del Trabajo (CGT), la detención de ex líderes políticos y sindicales peronistas, y también la purga de militares presuntamente simpatizantes del régimen depuesto.

Ahora bien, dentro de este panorama cabría preguntarse por la actitud que tomaron las huestes peronistas frente a los intentos "desperonizadores" del gobierno militar y también de la administración civil que lo siguió, la del radical intransigente Arturo Frondizi. En el caso del sindicalismo peronista, los trabajadores emprendieron, luego de la "Libertadora", un proceso de reorganización a los fines de mantener las conquistas sociales y laborales que habían logrado bajo el gobierno peronista. Se trató, no obstante, de un movimiento localizado y esporádico, como lo atestiguan las huelgas en defensa de delegados gremiales en la planta metalúrgica CATITA en diciembre de 1955, en el frigorífico Lisandro de la Torre en abril del año 56 y en los frigoríficos Swift de las localidades de Rosario y Berisso, en junio del mismo año.

En este sentido, en el transcurso del año 56, como sostiene Alejandro Schneider, los trabajadores fueron adquiriendo un "notable saldo organizativo que se tradujo en la formación de agrupamientos sindicales que superaron los límites impuestos por las entidades laborales". Así, para 1957, el activismo gremial combativo - una nueva camada de dirigentes en el seno del movimiento obrero- comenzó a "aunar sus fuerzas con el fin de disputar un espacio dentro de los resquicios legales que dejaba el régimen militar". Precisamente, en aquel año nacerían las "62 Organizaciones Peronistas", punto culminante de un proceso que se había iniciado con la recuperación de las comisiones internas, de los cuerpos de delegados y también de los sindicatos. ${ }^{2}$ Autopresentadas como el brazo político del gremialismo peronista, el surgimiento de las "62" "no sólo confirmó la dominante posición de los peronistas en los gremios, sino que además les proporcionó una entidad totalmente peronista" 3 con la cual actuar y presionar al gobierno militar tanto en la esfera política como en la sindical. Esto mostró, asimismo, que los gremios constituían la fuerza fundamental de organización y expresión institucional del peronismo tras el derrocamiento y exilio de su líder.

A partir de 1958, con el gobierno electo de Arturo Frondizi, en cambio, el sindicalismo peronista tuvo una efímera luna de miel de apenas tres meses: se consagraron aumentos salariales, se legalizó la simbología peronista, se derogó la interdicción que pesaba sobre dirigentes políticos y sindicalistas peronistas y, quizás más importante aún, se restauró la antigua ley de Asociaciones Profesionales de año 45. Empero, la crisis crónica en la balanza de pagos obligó al gobierno radical a llevar adelante un implacable plan de estabilización económica, a cambio de un suculento desembolso por parte del Fondo Monetario Internacional (FMI). La ejecución del plan y la consiguiente recesión económica que trajo aparejada, unida, a su vez, a la dura derrota sindical de enero de $1959^{4}$ y a la

\footnotetext{
${ }^{2}$ Alejandro Schneider, Los compañeros, Buenos Aires, Imago Mundi, 2005, 104.

${ }^{3}$ Daniel James, Resistencia e integración, Sudamericana, 1990, 112.

${ }^{4}$ El plan de estabilización de Frondizi involcró también la privatización del Frigorífico Nacional Lisandro de la Torre, ubicado en el barrio porteño de Mataderos. Este intento derivó en la toma de sus instalaciones por sus empleados, el 15 de enero de 1959. En solidaridad, las "62 Organizaciones" convocaron a una huelga
} 
férrea represión obrera en la que se embarcó el gobierno de Frondizi con el Plan CONINTES $^{5}$ a partir de marzo de 1960, condujo a importantes transformaciones en el sindicalismo peronista. Por un lado, disminuyeron el número de huelgas, ${ }^{6}$ numerosos dirigentes sindicales peronistas importantes fueron detenidos o colocados en listas negras, se debilitaron las comisiones internas de las fábricas debido a la represión sistemática hacia los activistas de base, asimismo metalúrgicos, textiles y otros sindicatos industriales fueron obligados a hacer importantes concesiones al gobierno. Por el otro, un grupo de dirigentes intermedios comenzó a ver con mayor desconfianza la actitud de intransigencia absoluta y oposición a ultranza al gobierno, la cual, entendían, no continuaba siendo una actitud del todo provechosa para el movimiento obrero. El militantismo obrero combativo e intransigente parecía estar marchitándose.

Para principios de los años sesenta, tres fracciones eran claramente identificables en las "62 Organizaciones". En primer lugar, en uno de los extremos, estaban los "blandos". Éstos habían trocado la movilización y la acción directa por huelgas generales controladas por las cúpulas gremiales. Este sector estaba compuesto tanto por los "intregracionistas", los que mantenía una actitud legalista y pasiva a los fines de retener sus sindicatos, como también por los "vandoristas", predispuestos por la negociación y el compromiso con el gobierno pero siempre prestos a recordarle su poder-. ${ }^{7} \mathrm{Si}$ bien los "integracionistas" no pudieron sobrevivir al golpe de Estado a Frondizi en marzo de 1962, el sector "vandorista" cobraría real importancia en los años subsiguientes, ahondando aún más las diferencias entre Perón y el líder del sector, Augusto Timoteo Vandor. Frente a los "blandos", se encontraban los "duros", aquellos que anhelaban crear un clima de ingobernabilidad tal que obligase al Frondizi y a las Fuerzas Armadas a permitir el retorno de Perón. Eran dirigentes

general. Sin embargo, la huelga terminó, dos días después, con una aguda represión y con la detención de importantes dirigentes sindicales. Al respecto, puede verse un relato de este episodio y sus repercusiones en Ernesto Salas, La Resistencia Peronista. La toma del frigorífico Lisando de la Torre, Buenos Aires, Altamira, 2006.

${ }^{5}$ El plan de Conmoción Interna del Estado -o CONINTES, por sus siglas- es el nombre que recibieron una serie de disposiciones del Poder Ejecutivo durante el gobierno de Arturo Frondizi (1958-1962), las cuales dotaron a las Fuerzas Armadas del poder para intervenir, vía represión, en los conflictos políticos internos. Como argumenta Esteban Pontoriero, tras el conflictivo año 59, la puesta en vigor del CONINTES resultó altamente efectiva; se redujeron considerablemente la cantidad de huelgas mediante la intensa represión estatal y la detención de militantes peronistas, que redundó en una notable desmoralización de las bases sindicales más belicosas para con el gobierno de Frondizi y su política económica. Asimismo, entre 1958 y mitad de 1961, disminuyeron drásticamente los "actos terroristas" (bombas y petardos, incendios, sabotajes industriales y al transporte público, ataques individuales, etc.): de 914 registrados para 1958, se pasó a 51 en junio de 1961 para todo el territorio nacional. Esteban Pontoriero, "Estado de excepción y contrainsurgencia: el Plan Conintes y la militarización de la seguridad interna en la Argentina (1958-1962)”, Contenciosa, II, No4, 2015, p. 9. Para ampliar sobre la repercusión del CONINTES en la militancia peronista, ver Nicolas Damin, Plan Conintes y Resistencia Peronista, 1955-1973, Buenos Aires, Instituto Juan Domingo Perón, 2010.

${ }^{6}$ Mientras en 1959 se llegó al pico máximo de diez millones de días perdidos por huelga, para 1960-1961 éstos decayeron abruptamente a poco más de un millón, siendo en 1962 apenas 268.000 días perdidos. James, op. cit., 166.

7 Marcelo Raimundo, “Compañero y los orígenes del Peronismo Revolucionario”, Sociohistórica, 8, 2001, 205. 
de sindicatos relativamente pequeños y con poco poder para negociar frente a las patronales y al Estado. ${ }^{8}$

Ahora bien, no puede ser del todo una sorpresa que lo que se constituyó como el sector juvenil del peronismo tuviese simpatías para con los "duros" del sindicalismo. Asimismo, tampoco puede resultar una novedad que los "blandos", aquellos que apostaban por una actitud más conciliadora con Frondizi, se hayan constituido en los más acérrimos enemigos de los sectores juveniles peronistas. Se trataba de jóvenes "peronizados" que pretendieron no sólo ser reconocidos como interlocutores válidos dentro del movimiento. Se orientaron preponderantemente a disputarle poder a otros actores desde adentro. En su acelerado proceso de radicalización, los sectores juveniles comenzaron a impugnar a dirigentes partidarios peronistas ${ }^{9}$ en lo que era su renuencia a llevar adelante las proclamas insurreccionales de Perón. Estas eran consideradas por los jóvenes como llamamientos inmediatos a la acción.

Tal y como acertadamente lo marca Sergio Pujol, los jóvenes argentinos de comienzos de los sesenta reflejaron, tanto en sus prácticas sociales como también en su producción artística, el "malestar de una época que acababa de pasar velozmente del sueño desarrollista a la realidad más modesta $-\mathrm{y}$ tardíamente valorizada- del gobierno del radical Arturo Illia". ${ }^{10}$ Estos primeros años sesenta se caracterizaron, asimismo, por un acercamiento de la juventud hacia el peronismo, correlato de la emergencia de una cultura contestataria, ligada íntimamente a un ethos de compromiso político juvenil, que apostaba fervientemente por el involucramiento político y por la acción directa. Al decir de Mónica Bertolucci, los jóvenes comenzaron a interpretar el peronismo bajo sus propios esquemas, sin certezas de que el sector tradicional del peronismo los aceptara. ${ }^{11}$ Un conjunto de ideas fuerza tan disímiles como transformar las estructuras políticas, económicas y sociales, un revival nacionalista o prédicas en favor de la lucha contra los imperialismos y las empresas extranjeras, comenzaron a configurar imaginarios sociales comunes dentro y también fuera del peronismo. ${ }^{12}$

El trabajo que se presenta a continuación busca examinar cómo fue reelaborada la tradición peronista por uno de los primeros nucleamientos juveniles organizados luego del

\footnotetext{
${ }^{8}$ James McGuire, "Perón y los sindicatos: la lucha por el liderazgo peronista", Samuel Amaral y Mariano Ben Plotkin (comp.), Perón: del exilio al poder, San Martín, Cántaro, 1993,185-186.

${ }^{9}$ No obstante, Bozza sostiene que, en la primera mitad de los sesenta, la Juventud Peronista no llevó adelante una consistente prédica antiburocrática. Esta aserción es bastante discutible. Por ejemplo, el grupo encargado de Trinchera de la Juventud Peronista, la "Mesa Ejecutiva de la Juventud Peronista de la Capital Federal y el Gran Buenos Aires", esbozó una incipiente pero coherente crítica hacia los sectores gremiales que comenzaron a vincularse más activamente con el gobierno de Frondizi y sus sucesores militares. Juan Bozza, "El peronismo revolucionario. Itinerario y vertientes de la radicalización, 1959-1969", Sociohistórica, 9, 2001, 151.

${ }^{10}$ Sergio Pujol, "Rebeldes y modernos. Una cultura de los jóvenes", en Daniel James (dir.), Violencia, proscripción y autoritarismo (1955-1976), Buenos Aires, Sudamericana, 2003, 294.

${ }^{11}$ Mónica Bertolucci, "Los hijos peronistas 1955-1966", Segundo Congreso de Estudios sobre el Peronismo (1943 - 1976), Red de Estudios sobre el Peronismo, Universidad Nacional de Tres de Febrero, 2010, 8.

12 Mónica Gordillo, "Protesta, rebelión y movilización: de la resistencia a la lucha armada, 1955-1973", Daniel James (dir.), Violencia, proscripción y autoritarismo (1955-1973), Buenos Aires, Sudamericana, 2003, 336.
} 
derrocamiento de Perón: la "Mesa Ejecutiva de la Juventud Peronista de Capital Federal y Gran Buenos Aires". Para ello, se analiza la publicación insignia de la organización, Trinchera de la Juventud Peronista. A partir de ésta, se pretende examinar el modo en que fueron entendidos "los años peronistas", haciendo foco especialmente en el "17 de Octubre" y en el golpe de Estado de 1955. Asimismo, se buscan estudiar las construcciones que se hicieron de las figuras de Juan Domingo Perón y de Eva Perón. El presente trabajo, entonces, está estructurado en dos partes. La primera de ella obedece a una suerte de presentación de la "Mesa" y su publicación. La segunda es un análisis específico de la constitución de la tradición peronista en Trinchera.

Un examen riguroso de los modos lectura que se hicieron de la experiencia peronista puede arrojar luz sobre el proceso de transformación del peronismo entre finales de los años sesenta y principios de los setenta. Asimismo, un ejercicio como el que aquí se intenta llevar a cabo, ayuda a desandar numerosas lecturas que se han hecho sobre el periodo, las cuales han pretendido encontrar en los años inmediatamente posteriores al derrocamiento de Perón, las claves interpretativas del derrotero que siguieron actores individuales y colectivos en los convulsionados y sangrientos años setenta. Este trabajo, entonces, trata de restituir la complejidad del fenómeno sin por eso horadar su capacidad explicativa. Reponer la espesura obturada es el primer paso para una comprensión cabal de la riqueza del peronismo en los años sesenta.

\section{La Mesa Ejecutiva y su boletín. La JP "bajo fuerzas de ocupación”}

A finales de la década de los cincuenta, existían en distintos barrios de la Capital Federal, del Gran Buenos Aires, de la ciudad de La Plata y en otras ciudades del interior de la Argentina, grupos juveniles que se presentaban como peronistas. Se trataba, como lo muestra muy bien Laura Ehrlich, de jóvenes nacidos entre 1935 y 1945, aquellos que habían crecido durante el gobierno peronista. ${ }^{13}$ Muchos de estos "jóvenes peronistas" confluirían en la constitución de la "Mesa".

Ahora bien, entre 1958 y 1959, como corolario del estrechamiento de vínculos y la coordinación de tareas y actividades, se constituiría la "Mesa". El "Comando General Valle" comenzó una serie de reuniones con otros pequeños grupos que se autopresentaban como pertenecientes a la Juventud Peronista (JP): "Juventudes de Perón", "Montoneros de Perón", "Guardia de Hierro" y varias más que, sin tener un nombre preciso, se anunciaban como JP de barrios de la Capital Federal o de zonas del Gran Buenos Aires -la "Juventud de Villa Soldati", la "Juventud de Once", la "Juventud de Bernal", el "Comando Revolucionario Peronista" y "Ateneo 17 de Octubre”, por mencionar algunas-. Éstas serían las firmantes de la "Coordinadora Provisoria de la Juventud Peronista" en 1958, a todas luces prolegómeno de la "Mesa Ejecutiva de la Juventud Peronista de Capital Federal y de

\footnotetext{
${ }^{13}$ Laura Ehrlich, "Los espacios de sociabilidad en la estructuración de la Juventud Peronista post '55 en la ciudad de Buenos Aires", Apuntes de investigación del CECYP, XVI, 21, 2012, 159.
} 
Gran Buenos Aires". En este sentido, puede sostenerse con seguridad que la JP como tal se constituyó institucionalmente durante los primeros años de la proscripción peronista. ${ }^{14}$

La creación de la "Mesa", como relata uno de sus integrantes, Jorge Rulli, coincidió con dos hechos que dejarían marcas indelebles en el imaginario de la JP. ${ }^{15} \mathrm{El}$ primero de ellos fue la toma del Frigorífico Nacional Lisandro de la Torre en enero de 1959. Para algunos de estos jóvenes militantes, la toma y posterior represión gubernamental se convirtieron en una suerte de bautismo de fuego; era la primera oportunidad que muchos de ellos tenían de participar activamente, y junto a los trabajadores, en acciones contra el gobierno de Frondizi. El segundo de los hechos que menciona Rulli fue la aparición pública y luego detención de los "Uturuncos" en Tucumán en el mismo año 59, considerada como la primera guerrilla rural de la Argentina. A pesar de su exigua existencia -las fuerzas de seguridad desarmaron el pequeño campamento y detuvieron a los guerrilleros en cuestión de días- insinuó para muchos peronistas otra modalidad de lucha en el marco que ofrecía la Argentina del proscripto movimiento liderado por Perón. ${ }^{16}$

La creación de una coordinación nacional como era la "Mesa" introdujo un hecho nuevo: muchos de los grupos de la JP comenzaron a establecer sentidos vínculos con los sindicatos y con líderes gremiales. A decir de Mabel Di Leo, militante de la JP de Vicente López en aquellos años, esto condujo a que toda la actividad de los grupos juveniles estuviese determinada y condicionada por la cantidad de plata que los sindicatos les podían ortorgar. Algunos jóvenes militantes, incluso, llegaron a trabajar como guardaespaldas o grupos de choque de los propios sindicalistas. Para la Di Leo, "[e]sto fue lo que pudrió muchas cosas en la JP"; ${ }^{17}$ las divisiones arreciaron y comenzaron a surgir problemas dentro de la organización recién formada.

En este sentido, puede concluirse que la "Mesa" estuvo atravesada por conflictos prácticamente desde su nacimiento. La aplicación sistemática del CONINTES en 1960 encarceló a un número importante de sus miembros principales. La necesidad de llevar adelante una reorganización en vista a la cantidad de sus dirigentes de primera línea presos, produjo tensiones entre los sectores liderados por Alberto Brito Lima, más vinculado a la estructura partidaria, y el de Gustavo Rearte. Luego de perder una votación con la que intentó hacerse con la estructura de la coordinación nacional de la JP, Brito Lima y los suyos fueron expulsados. Obviamente, esta la depuración no acabó con los conflictos internos. En el transcurso de pocos años, las rencillas intestinas terminaron horadando y atomizando a la organización.

\footnotetext{
14 Acha ha marcado que los comienzos de la JP pueden asimismo retrotraerse a los años del gobierno peronista. Mientras en diciembre de 1951 se llevaron a cabo las reuniones constitutivas del Movimiento de la Juventud Peronista de la República Argentina - un intento de ligar y darle forma a la pluralidad de experiencias jóvenes del peronismo que iban surgiendo a comienzos de los cincuenta-, en 1953 apareció en escena este sector de la juventud, en ocasión de las celebraciones del "Día de la Libertad" en la ciudad de La Plata. Para ampliar a este respecto, ver Omar Acha, Los muchachos peronistas. Orígenes olvidados de la Juventud Peronista (1945-1955), Buenos Aires, Planeta, 2011.

${ }^{15}$ Oscar Anzorena, Historia de la Juventud Peronista 1955-1988, Buenos Aires, Del Cordón, $1989,34$.

16 Para ampliar respecto de ambos episodios, se recomiendan: Ernesto Salas, op. Cit. y Ernesto Salas, Uturuncos. El origen de la guerrilla peronista, Buenos Aires, Biblos, 2003.

${ }^{17}$ Anzorena, op. Cit., 53
} 
El descabezamiento de la "Mesa", en definitiva, obligó a algunos de sus miembros a asumir tareas con carácter de urgencia y para la que muchas veces no estaban preparados. Este fue el caso de Beatriz Fortunato, la que se convirtió en poco tiempo en su máxima responsable. No obstante, al poco tiempo los sectores de Brito Lima y El Kadri, disidentes de la conducción del por entonces preso Gustavo Rearte, comenzaron a confrontar con Fortunato. ${ }^{18}$ Finalmente, luego de boicotear todo intento por reorganizar la "Mesa", El Kadri y los suyos tomarían el nombre de Trinchera y reeditarían la publicación en 1964. En los años subsiguientes, muchos de los formantes de la "Mesa" continuarían sus actividades en distintas organizaciones. Por ejemplo, Brito Lima fundaría el "Comando de Organización" en 1961 y mantendría a su organización funcionando hasta bien entrados los años setenta. Asimismo, Gustavo Rearte y Envar El Kadri serían fundadores y líderes del "Movimiento Revolucionario Peronista" (MRP) y de las "Fuerzas Armadas Peronistas" (FAP) en 1964 y en 1966, respectivamente.

Ahora bien, en su efímera existencia, entre 1960 y 1963, la "Mesa" editó, como se mencionó más arriba, Trinchera de la Juventud Peronista, una modesta y semiclandestina publicación de 14 páginas impresas a mimeógrafo, cuyos artículos no llevaban firma pero que en cada uno de sus diecisiete números se firmaba con la leyenda "bajo fuerzas de ocupación". Su comité de redacción estuvo conformado por Beatriz Fortunato, Envar El Kadri, Héctor Spina, los hermanos Gustavo y Alberto Rearte, Felipe Vallese y Jorge Rulli, por sólo mencionar a los más importantes. La publicación, no obstante, tuvo una circulación bastante irregular, producto no sólo de la artesanal forma en la que fue confeccionada y distribuida sino también debido a la persistente persecución y encarcelamiento de sus redactores. ${ }^{19}$

Para concluir, debe destacarse que Trinchera no tuvo bajo ningún punto de vista una estructura fija. Sin embargo, es posible percibir a lo largo de sus números ciertas constantes. Por un lado, los comentarios realizados respecto de los mensajes emitidos por Perón en su exilio. Luego, no sólo el persistente recordatorio a los militantes peronistas torturados, encarcelados o muertos, sino también la identificación de aquellos militares y jefes policiales vinculados con la represión. Y por el otro, las apostillas relacionadas con los movimientos de liberación nacional y las guerras que se estaban librando en el "Tercer Mundo".

\section{La "Mesa" y la tradición peronista}

En su trabajo Las dos fronteras de la democracia argentina, Aboy Carlés asegura que toda identidad socio-política -entendida como una práctica sedimentada que configura

\footnotetext{
${ }^{18}$ A los fines de profundizar en estas polémicas así como también en el rol de Fortunato, se sugiere: Florencio Monzó (h), Llegó carta de Perón, Buenos Aires, Corregidor, 2006.

19 El carácter semiclandestino de la publicación ha ocasionado que algunos de sus números fueran inaccesibles al día de la fecha. No obstante esto, y a los fines que persigue el presente estudio, aquellos ejemplares existentes pueden ser utilizados para desentrañar los modos de construcción y las formas que adoptó la tradición peronista en esta primera Juventud Peronista. Facundo Carman, El poder de la palabra escrita. Revistas y periódicos argentinos (1955-1976), Buenos Aires, Biblioteca Nacional, $2015,661$.
} 
sentido y establece solidaridades estables- es pasible de ser dividida analíticamente en tres dimensiones: la alteridad, la representación y la tradición. Mientras las dos primeras hacen referencia a los procesos simultaneos de diferenciación externa y homogenización interna de todo conjunto, la tradición se relaciona con la erección de un "sistema temporal en el que la interpretación del pasado y la construcción del futuro deseado se conjugan para dotar de sentido a la acción del presente". ${ }^{20}$ Esto es, la "perspectiva de la tradición" marca que las construcciones discursivas elaboradas alrededor del pasado tienen capital importancia para la constitución presente y futura de todo conjunto gregario; historia y política, debe seguirse de esta aserción, conviven -usualmente en una tensión permanente- en cualquier procesos identificatorio.

Haciendo eco de las reflexiones pretéritas, aquí se entiende que referirse a tradiciones políticas implica, como primer paso, desestimar aquellos acercamientos que pretenden circunscribirlas dentro de límites y contornos fijos e invariables. En otras palabras, involucra ir contra las visiones genealógicas; esto es, aquellas que ven a las tradiciones meramente como un conjunto homogéneo de preceptos derivados de un proceso evolutivo.

Contra estas tentativas y desde una concepción epistemológica rizomática, ${ }^{21}$ aquí se conciben a las tradiciones como reconstrucciones de sentido que no se caracterizan por ser objetivas, lineales y mucho menos uniformes. En otras palabras, no existen tradiciones puras e impolutas, sino más bien todas ellas son recortes, trazos sobre trazos, sedimentos sobre sedimentos. Una tradición, en definitiva, es una narración "inventada" -nunca ex nihilo- sobre los orígenes y el devenir de un conjunto gregario. Es, apelando a otros términos, un discurso ${ }^{22}$ sobre la heredad y el porvenir. El proceso de conformación y transformación de una tradición no sigue, entonces, un proceso lógico y progresivo. Se destaca, en cambio, por ser contingente y altamente aleatorio; esto es, los temas -conjuntos de palabras e imágenes- a partir de los cuales se compone y transforma una tradición nunca pueden ser develados a priori. Lo que se tienees un producto un tanto apelmazado y compacto, pero siempre en constante cambio.

El investigador interesado en develar los contornos difusos y las significaciones complejas que intervienen en la confección y mutación de una tradición debe partir, como se mencionaba más arriba, considerando la naturaleza ficcional de las historias; en otras palabras, que éstas se escriben para y desde el presente, a los fines de dotar de sentido al "aquí y ahora" de unos narradores. Entonces, si un actor en particular se sirve del pasado, desempolvando los artefactos de viejos anaqueles, lo hace para brindar un conjunto de certezas y conocimientos -quiénes fueron, son y buscan ser en un futuro- a los que se dirige. Esta inacabada y persistente reescritura del pasado constituye un arma fundamental a la hora de polemizar y descalificar a los enemigos y adversarios políticos de turno. ${ }^{23}$

\footnotetext{
${ }^{20}$ Gerardo Aboy Carlés, Las dos fronteras de la democracia argentina, Rosario, Homo Sapiens, $2001,68$.

${ }^{21}$ Giles Deleuze y Felix Guattari, Capitalismo y esquizofrenia. Mil Mesetas, Valencia, Pre-Textos, 2002.

22 Aquí se entiende al discurso como una práctica articulatoria de elementos. Ernesto Laclau y Chantal Mouffe, Hegemonía y estrategia socialista, Buenos Aires, FCE, 2010, 143.

23 Compleja como el propio desentrañamiento de la tradición, las palabras arriba esbozadas pueden complementarse con otros trabajos. Acerca de una concepción novedosa a la hora de considerar la nación, se
} 
Con las reflexiones pretéritas presentes y centrando la atención en Trinchera, surgen algunas preguntas. Por un lado, ¿de qué modo fueron presentados los "años peronistas" (1946-1955) por los jóvenes de la "Mesa"? Luego, ¿cuál fue el lugar que asignaron a las figuras de Perón y Eva Perón? También, ¿cómo fue narrado el golpe de Estado de 1955? Y, por el otro, ¿qué significó el "17 de Octubre? En definitiva, la cuestión se refiere al modo en que fue presentada la tradición peronista por los jóvenes militantes peronistas de comienzos de los años sesenta. ${ }^{24}$ Lo que sigue será un intento por responder estas preguntas.

\section{Los años peronistas entre fronteras: el "17 de Octubre" y el golpe de Estado de 1955}

No podría resultar una sorpresa que los redactores de Trinchera concibiesen al 17 de octubre de 1945 y al golpe de Estado que derrocó a Perón diez años después como marcas de una ruptura, índices de la erección fronteras políticas. ${ }^{25}$ Ambas cesuras, empero, no construyeron un pasado, dieron sentido al presente ni planificaron un futuro deseado de la misma manera. Mientras el "Día de la Lealtad" - como el peronismo denominó al 17 de octubre del año 45- simbolizó, para la publicación, un quiebre respecto a un pasado vivido como oprobioso. Una ruptura vinculada, a grandes trazos, con la marginación política y el sojuzgamiento económico de las mayorías populares. En este sentido, el golpe de 1955 fue concebido como una interrupción violenta respecto de ese momento de redención que simbolizaron los nueve años de gobierno peronista.

Comenzado por el "17 de Octubre" y teniendo presente esa función de frontera, quiebre o marca bajo el cual fue simbolizado, asaltan una serie de preguntas: ¿Cómo fue presentado por estos jóvenes peronistas? ¿Qué elementos le incorporaron a la clásica festividad peronista? ¿Cuál fue la característica distintiva que estos noveles miembros movimiento peronista le adjudicaron al fervoroso "Día de la Lealtad"?

Para los miembros de la Mesa no existían dudas: el "17 de Octubre" se trató de una "verdadera revolución, es decir, un cambio de estructuras, que quiebra definitivamente los fundamentos del Estado Liberal Burgués". ${ }^{26}$ Fue, en otras palabras, una ruptura con los modos y contenidos de los gobiernos anteriores, caracterizados por producir constantes vejaciones y humillaciones hacia las mayorías populares. Para los jóvenes peronistas, estas afrentas hacia los sectores populares trascendieron gobiernos, partidos y nombres propios a

puede reparar en Ernest Renan, ¿Qué es la nación?, Buenos Aires, Hydra, 2010. Para desentrañar las vicisitudes del discurso antigenealógico renaniano, ver Elías Palti, La nación como problema. Los historiadores y la “cuestión nacional”, Buenos Aires, FCE, 2002. Para profundizar sobre el carácter ficcional de las tradiciones, ver Eric Hobsbawm y Terence Ranger, La invención de la tradición, Barcelona, Crítica, 2002.

${ }^{24}$ Las exiguas representaciones pictóricas que se encuentran en Trinchera no son analizadas en este trabajo. La principal razón de ellos obedece al escaso margen del que se dispone. Futuros trabajos, no obstante, deberían embarcarse en un análisis detallado de aquellas representaciones, a los fines de complejizar aún más los resultados del estudio aquí presentado.

${ }^{25}$ Aboy Carlés, op. cit.

26 "La Revolución Peronista", Trinchera de la Juventud Peronista, 2, 9, 7/1961, 1. 
lo largo de la historia argentina. Esa era la razón, podría asegurarse, de las prácticamente inexistentes referencias a partidos o figuras políticas con anterioridad al año 45.

Es posible establecer con seguridad que el índice de esa cesura obedecía a que, a partir de aquella calurosa jornada del mes de octubre, el pueblo argentino pareciera haber adquirido conciencia, no sólo de la situación en la que se encontraba antes del "rescate" de Perón del Hospital Militar, sino principalmente en que, a partir de este hecho, el pueblo comprendió qué es lo que quería y hacia dónde debía ir en consecuencia. ${ }^{27}$ Este fue, como dicen los redactores de Trinchera, el momento del "despertar aletargado del león del Pueblo Argentino, que sacudió su melena a instigación de un Coronel de machos". ${ }^{28}$ Perón, en esta circense caracterización, parece haber convencido inmediatamente a los trabajadores movilizados en pos de su liberación, los cuales, habiendo oído y seguido a su líder, "fueron conducidos al triunfo en el $45 " .29$

En relación con esto último, sería de utilidad recordar las palabras que respecto de las celebraciones del "17 de Octubre" hicieron Mirta Zaida Lobato y Lizel Tornay. Según las autoras, el discurso dado por Perón en las celebraciones del año 46 marcó:

El sentido plebiscitario que tendría la jornada del 17 de octubre puesto que a partir de entonces el Presidente se comprometía a interrogar al pueblo sobre la marcha de su gobierno. El 17 de octubre, en palabras de Perón, fue una epopeya de los descamisados cuya marca distintiva era el vínculo que se establecía entre el pueblo y el líder. ${ }^{30}$

A partir de esto, es posible sostener que desde Trinchera se reproducía esta idea sobre el vínculo entre Perón y su pueblo. El lazo entre el líder y su pueblo se remontaba, entonces, a los propios comienzos del peronismo; esto es, a su fecha fundacional. En esta "epopeya", las huestes peronistas no sólo parecen haber ganado conciencia -como más arriba se especificó- sino también la posibilidad de expresarle a su líder el estado de la unión, la fortaleza del vínculo, la salud del lazo tejido ese 17 de octubre del año 45.

Asimismo, el "17 de Octubre" constituyó, para los jóvenes de la "Mesa", el momento en el que el "Pueblo quemo para siempre lo que fueran los instrumentos ideológicos de poder". ${ }^{31}$ Fue también, y quizás en el mismo tenor, un momento de construcción, en el que las "banderas de la Doctrina Nacional Peronistas eran la Independencia, la Soberanía y la Justicia". ${ }^{32}$ Estás constituirán las piedras fundacionales del régimen peronista, caracterizado por la publicación como el momento de:

\footnotetext{
${ }^{27}$ Idem.

28 "17 de Octubre", Trinchera de la Juventud Peronista, 1, 3, 10/1960, 1.

${ }^{29}$ Idem.

${ }^{30}$ Mirta Zaida Lobato y Lizel Tornay, "La política como espectáculo: imágenes del 17 de Octubre”, Santiago Senén Gonzalez y Gabriel D. Lerman (comp.), El 17 de octubre de 1945. Antes durante y después, Buenos Aires, Lumiere, 2005.

31 "No olvidar...", Trinchera de la Juventud Peronista, 2, 9, 07/1961, 8.

32 Idem.
} 
La formación de una industria que aseguraba al país plena ocupación y que se encontraba en el camino de satisfacer todas las necesidades que garantizaran su Soberanía Política fue posible por las adecuadas medidas económicas que el gobierno de Perón adoptó con el apoyo de los trabajadores. ${ }^{33}$

En clara contraposición a la situación económica por la que atravesaba la Argentina de principios de los años sesenta, como un índice a través del cual denunciar la crisis económica y política del sucesor de Frondizi, José María Guido, los miembros de la "Mesa" construían una imagen muy precisa de lo que constituyó el gobierno peronista. Se referían a un gobierno que llevó adelante un millar de obras -76.000, según sus cálculos-, que constituyó un "IAPI [Instituto Argentino de Promoción del Intercambio] defensor del comercio exterior (...) $[\mathrm{u}] \mathrm{n}$ Banco Central regulador de la economía (...) [u]na Industrialización en Marcha base de nuestra Liberación Nacional (...) [u]na CGT Argentina y poderosa"; 34 todo esto sólo posible por la conducción estratégica de Perón y el apoyo táctico que los trabajadores dieron a su líder.

Asimismo, el régimen peronista, para Trinchera, fue quien primero llamó la atención a los países subdesarrollados del mundo acerca de la necesidad de asumir una posición independiente tanto de los Estados Unidos como tamién de la Unión Soviética. En los albores de las luchas sesentistas de liberación nacional en Asia y África, los jóvenes peronistas de la "Mesa" verían en ellas concretizado el pretérito llamamiento peronista por una "Tercera Posición". Sin embargo, este retorno al término estaría ahora cargado de un nítido contenido combativo; significaba no sólo "lucha por la emancipación nacional y popular", en estrecha ligazón con otros pueblos, sino también una "superación de los antagonismos en pugna", 35 posición que podría o no coincidir circunstancialmente con los intereses occidentales u orientales. En pocas palabras, solidaridad con los movimientos de liberación nacional e independencia respecto de los bloques dominantes, Estados Unidos y la Unión Soviética.

En contrapartida, a la conspiración militar triunfante de septiembre del 55 se la identificó con el momento en que las banderas izadas el "17 de Octubre" trocaron en "Prebenda, Tilinguearía y Falsías", 36 índices que explicarían la concatenación de conspiraciones y ataques que sufrió el gobierno peronista y que, con el correr de unos pocos años, derivaron en el golpe: ${ }^{37}$

[El] 28 de septiembre de 1951 [Levantamiento del General (r) Benjamín Menéndez] - Abril de 1954 [Aquí el año correcto seguramente es 1953,

\footnotetext{
33 "El giro a la izquierda...", Trinchera de la Juventud Peronista, 3, 17, 04/1963, 5.

34 "No olvidar...", Trinchera de la Juventud Peronista, 2, 9, 07/1961, 8.

35 "La reunión de Belgrado", Trinchera de la Juventud Peronista, 2, 12, 10/1961, 3.

36 "17 de Octubre", Trinchera de la Juventud Peronista, 1, 3, 10/1960, 1.

${ }^{37}$ Resulta interesante anotar que en el último discurso conmemorativo de Perón del "Día de la Lealtad" en 1954, en medio de un panorama político y social extremadamente conflictivo, los significantes "[1]ealtad y deslealtad se articularon como pares dicotómicos que permitían denunciar a todos los opositores, incluso a los del propio movimiento". Lobato y Tornay, op. cit., 235.
} 
cuando se sucedieron los violentos ataques del grupos antiperonistas en una manifestación organizada por la CGT en Plaza de Mayo en apoyo al nuevo rumbo económico que estaba tomando el gobierno de Perón] Matanzas en concentraciones peronistas - 16 de Junio [Bombardeo sobre Plaza de Mayo] - Crimen de Lesa Humanidad - 16 al 22 de septiembre de 1955 [el Golpe de Estado] - Atemorización, crímenes y desapariciones. ${ }^{38}$

Podría decirse que el golpe septembrino simbolizaba para estos jóvenes el momento de la "caída", en que los dulces y felices años peronistas se transformaron en tortura y confinamiento, vejaciones, fusilamientos y cárcel sus militantes. Sin embargo, éste no se circunscribió simplemente a los tres años que duró la "Libertadora" en el poder, sino que se expandió e intensificó con la implementación del CONINTES bajo el gobierno de Frondizi. ${ }^{39}$

No obstante, debe marcarse que, para los miembros de Trinchera, la irrupción de la "Libertadora" no se limitó meramente a la persecución de las huestes peronistas. Ella simbolizaba, como un complemento que ayudaba a explicar la persecución y el acoso al peronismo, la transformación de la "utopía peronista"; esto es, un cambio en el régimen económico. Para los jóvenes peronistas, luego del golpe se desmantelaron fábricas, creando desempleo, se entregaron las "radios, las televisiones y los periódicos a los enemigos de nuestras costumbres y tradiciones", ${ }^{40}$ lo que dio por resultado una "Patria entregada al extranjero", "convertida nuevamente en Colonia, sometida ahora a la prepotencia yanki". ${ }^{42}$ Sólo seis años bastaron a los responsables de golpe septembrino y a sus socios civiles posteriores para que se hiciese añicos, también, la clásica "Tercera Posición" peronista, despojando al país, como complemente, de su soberanía, su independencia y su justicia social, todo estos presuntos símbolos del gobierno peronista.

Hasta aquí, entonces, se mostró de qué manera fueron presentados en Trinchera tanto el "17 de Octubre", el golpe del 55, como también el régimen peronista. Mientras el primero de éstos fue desplegado como una verdadera revolución, primer ladrillo del régimen peronista, momento fundacional de la "dignificación de pueblo doliente", el levantamiento de septiembre simbolizó un intento por retornar al estado de cosas anterior a la jornada de octubre del 45; intento que las medidas económicas implementadas por la "Libertadora" y por los gobiernos civiles de Frondizi y Guido abonaban.

Sin embargo, esta pretendida regresión solo iba a quedar, a fin de cuentas, en un mero anhelo; la Juventud Peronista, eregida como una suerte de "reserva moral" del movimiento, sería la encargada de conducir "a la victoria final en el 60". ${ }^{43}$ Ella se autopresentaba como la encarnación de ese pueblo que victoriosamente había "liberado" a

\footnotetext{
38 "17 de Octubre", Trinchera de la Juventud Peronista, 1, 3, 10/1960, 1.

39 "Militares contra el Pueblo", Trinchera de la Juventud Peronista, 2, 10, 08/1961, 10; "Charlas de doctrina entre descamisados", Trinchera de la Juventud Peronista, 2, 12, 10/1961, 4.

40 "Genocidio", Trinchera de la Juventud Peronista, 1, 3, 10/1960, 9.

41 "9 de Julio", Trinchera de la Juventud Peronista, 2, 9, 07/1961, 5.

42 "Captura...", Trinchera de la Juventud Peronista, 2, 9, 07/1961, 10.

43 "La Juventud Peronista", Trinchera de la Juventud Peronista, 1, 3, 10/1960, 3.
} 
Perón, de los trabajadores con cuyo apoyo se construyó el Estado peronista, de la militancia que no iba a permitir que los vencedores del 55 arrasasen finalmente con el peronismo. La juventud, por otro lado, que lograría traer nuevamente al "Gran Conductor". ${ }^{44}$

Como muy bien lo señala Laura Ehrlich, este postularse como la avanzada por el retorno de Perón que hacía la Juventud Peronista "encontraba parte de su sentido en la pugna con otros sectores políticos internos", 45 a los que se acusaba de desviar al peronismo de la senda "revolucionaria", sea pactando con Frondizi o propiciando una institucionalización del peronismo, que colocaba a su exiliado líder fuera del tablero de juego político. En otras palabras, la JP buscaba no sólo deslegitimar la apuesta "neoperonista" sino también disputarle la representación de la verdadera esencia del peronismo a los sectores vinculados a la estrutura, principalmente al "Consejo Coordinador y Superior del Peronismo" (CCSP); organismo que se mostraba receloso de incorporar militante jóvenes en sus filas. ${ }^{46}$

Aún a pesar del fuerte impacto que causó la implementación del CONINTES, un ethos juvenil sacrificial fue adquiriendo importantes dimensiones. Se trataba allí de un joven peronista que luchaba denodadamente, incluso poniendo en riesgo su propia vida, por las banderas de la "Argentina peronista" y por regreso de su líder al país. Este ethos formaría parte sustancial de muchas de las organizaciones juveniles peronistas en los años posteriores a la disolución de la "Mesa". Eso es lo que podría derivarse del derrotero, ya mencionado, de algunos de los miembros principales de la "Mesa": Rearte y El Kadri.

\section{La razón y la pasión peronistas: las imágenes de Perón y Evita}

Las representaciones que desde Trinchera se hicieron de Perón y de Evita pueden circunscribirse a dos tipos de registros. Mientras Perón era identificado con la inteligencia fría, la razón en pos de la traza de tácticas y estrategias de resistencia y regreso, además de la conducción política de masas, Eva simbolizaba la pasión desenfrenada, la total obediencia a los designios del "Conductor"; el fanatismo y la entrega para con la causa peronista, aún a riesgo de cercenar su propia existencia. ${ }^{47}$

\footnotetext{
${ }^{44}$ Esto podría ejemplifcar aquello que Verón y Sigal han denominado la "construcción de un actor social imaginario que atraviesa el tiempo y el espacio". Esta construcción ocurre en la medida en que conflictos actuales son presentados como la configuración de disputas históricas. Esto permite, a su vez, no sólo dotar de sentido a la acción presente sino también reforzar la identidad del colectivo, enlazándose a una herencia común. Eliseo Verón y Silvia Sigal, Perón o muerte, Buenos Aires, Eudeba, 2014, 195.

${ }^{45}$ Laura Ehrlich, "Nacionalismo y arquetipo heroico de la Juventud Peronista a comienzos de la dedicada del 60", Anuario IEHS, 28, 2013, 43.

${ }^{46}$ Laura Ehrlich, "Los espacios de sociabilidad en la estructuración de la Juventud Peronista post '55 en la ciudad de Buenos Aires", Apuntes de investigación del CECYP, XVI, 21, 2012, 168.

${ }^{47}$ Sarlo, apelando a la clásica distinción weberiana, ha visto en las figuras de Perón y de Evita los epítomes de las éticas de la responsabilidad y de la convicción, respectivamente. Esto es, una ética guiada preponderantemente por la reflexión medios-fines y por las consecuencias derviadas de los actos y otra, en contrapartida, regida por la obligación moral y el seguimiento ferreo de principios. Beatriz Sarlo, "Eva Perón: algunos temas", Carlos Altamirano (ed.), La Argentina en el siglo XX, Buenos Aires, Ariel, 1999, 348-349.
} 
Para la "Mesa", Perón representaba la imagen del estratega genial que "a miles de kilómetros" se encontraba trabajando "sin cesar en la proyección y en la conducción de la ya en marcha Revolución Nacional", la que haría reinar en el pueblo, "el Amor y la Igualdad". ${ }^{48}$ Ahora bien, sólo podría concretarse el regreso de Perón si la Juventud se abocaba a luchar por su retorno, lo que debía entendérselo como una activa resistencia y enconada lucha que deviniese, en un tiempo no muy prolongado, en una insurrección popular. Es ahí donde la Juventud Peronista encontraba su tarea esencial: preparar el terreno para el ansiado desembarco del líder exiliado. Sólo mediante el efectivo e irrenunciable retorno de Perón, los sectores populares tendrían su anhelada redención. Como ponen en boca de un presunto obrero: mientras los políticos profesionales "hablan y no hacen nada", gastando la "plata en aviones y en portaaviones y al Pueblo, si protesta, lo meten en la cárcel”, los sectores populares sólo volverían a tener sus horas más felices con la "vuelta del Hombre [ya que] Él y Evita sí que no se olvidaron que lo mejor es el Pueblo". 49

Asimismo, únicamente a través del regreso de Perón la "Revolución peronista" retomaría su devenir truncado en 1955. Esto se traducía, para estos jóvenes, en que "[c]on su retorno incondicional al Poder exterminaremos a la oligarquía cipaya y a los imperialismos extranjeros". ${ }^{50}$ Por lo tanto, la vuelta del líder exiliado era simbolizada como el retorno del "General" al campo de batalla, a la conducción de su ejército, dispuesto a llevar adelante la guerra definitiva contra sus enemigos. Independientemente de las metáforas belicistas, aquella vuelta era concebida como el mecanismo a través del cual retornar al estado de cosas anterior a la "Revolución Libertadora".

Con este marco en mente, Trinchera, publicación que aseguraba estar "bajo fuerzas de ocupación", proponía para sus militantes el "modelo evitista" de abnegación, fanatismos y renunciamiento personal, bajo cuyo influyo iban a poder llevar adelante la lucha:

Es su Presencia. Es su Imagen. Es su Sonrisa. Es su Fanatismo. Es su Holocausto. Ella [Evita] nos ha impulsado a la lucha; nos ha protegido en el combate y en el monte; nos ha dado aliento y fe en las largas jornadas de exilio o cárcel. Su Presencia ha llenado de luz y esperanza a la noche triste que vive la Patria. ${ }^{51}$

Evita era invocada, entonces, como la imagen protectora de todo militante juvenil que combatía por el regreso de Perón. Eva era investida de un aura mística, dadora de tesón y voluntad a los grupos guerreantes. Era simbolizada, asimismo, como la esperanza futura, la cándida imagen que recordaba a los jóvenes militantes tiempos mejores. Como sostiene muy bien Marysa Navarro, en lo que fue la "Resistencia Peronista", la imagen de Evita adquirió una proyección diferente de la que tuvo en vida; era identificada "con los mejores años del peronismo, una época de bonanza, de cambios, de bienestar y alegría para el

\footnotetext{
48 “La vigilia del regreso", Trinchera de la Juventud Peronista, 1, 5, 03-04/1961, 14.

49 "Trinchera en villa miseria", Trinchera de la Juventud Peronista, 2, 12, 10/1961, 9.

50 "9 de Julio", Trinchera de la Juventud Peronista, 2, 9, 07/1961, 5.

51 "Evita", Trinchera de la Juventud Peronista, 1, 3, 10/1960, 5.
} 
pueblo que no se podía menos que añorar en contraste con la persecución, la cárcel y la miseria del presente", 52

A su vez, Evita era erigida como lo más puro del peronismo, la personificación de la confianza ciega en la causa peronista, la que había entregado su vida por ella. ${ }^{53}$ También, se la presentaba como la encarnación de un nexo inquebrantable, de un puente imperecedero, "[una] Alianza, [una] Unión indestructible, entre la clase trabajadora y su Líder", ${ }^{4}$ lazo soldado por su holocausto, el sacrificio de su vida, hecho por Perón y por su causa. ${ }^{55}$

Navarro marca que ya desde los tempranos 1948 y 1952, Evita "había sido el eje alrededor del cual se estructuró la relación líder descamisados. Era el nexo entre los dos, o como se llamaba ella misma, "el puente entre el líder y los descamisados", 56 Su muerte, continúa la autora, dejó un vacío que fue muy difícil de llenar para Perón, quién comenzó a asumir las funciones institucionales y simbólicas que había adoptado su segunda esposa. A su vez, independientemente de la autoría o no de Evita de La razón de mi vida o de Historia del peronismo, allí aparece delineada con claridad esa imagen de puente o nexo. No resultaría para nada descabellado sostener que esta reproducción que hace Trinchera esté relacionada con el hecho de que los jóvenes redactor de la publicación crecieron bajo el régimen peronista, donde aquellos libros tuvieron una importancia capital, sobre todo luego de la muerte de Eva Perón.

Para los redactores de Trinchera, el ejemplo de Evita no sólo estaba dado por la pasional virulencia de su fanática vida y su abyecta abnegación, sino también por la forma en que le sobrevino la muerte: Eva fue "quemando" su vida, ofrendándola a Perón. Era caracterizada por "su constante renunciamiento a vivir su propia vida para poder vivir, entregarse y quemarse en aras de las reivindicaciones de su Pueblo". 57

En resumidas cuentas, entonces, mientras Perón fue erigido como un estratega genial que, en en medio de su exilio, no se resignaba a la lucha, desarrollando y perginiando las estrategias para lograr su regreso - el cual simbolizaba, como no podría ser

\footnotetext{
${ }^{52}$ Marysa Navarro, Evita, Buenos Aires, Edhasa, 2007, 336.

${ }^{53}$ En su trabajo sobre la figura de Evita en el peronismo de los sesenta, Ehrlich sostiene que la presentación de una Evita "combativa y revolucionaria se desarrolló durante la primera mitad de la década del 60", teniendo como fondo los conflictos en torno de la institucionalización del peronismo. Buscaron remarcar la "lealtad" y la "entrega" de Evita para con Perón, presentándola también como un "emblema de lucha y del afán revolucionario de nuevas redes de militantes del peronismo". Laura Ehrlich, "Figuras de Eva Perón entre los peronistas en la década del 60", V Congreso de Estudios sobre el Peronismo (1943-2016), Resistencia, 2016. Inédito. Para ampliar sobre los homenajes hechos a Evita por los militantes peronistas durante el periodo 1955-1963, ver: Anabella Gorza, "Los homenajes a Eva Perón como prácticas de memoria en tiempos de la Resistencia peronista (1955-1963)", Anuario del Instituto de Historia Argentina, La Plata, $2016,1-22$.

54 "Evita", Trinchera de la Juventud Peronista, 2, 9, 07/1961, 13.

55 Similarmente, la organización político-militar "Montoneros", más de una década después y a través de $E l$ Descamisado, volvería a remarcar ese lugar intermedio de Evita, sin por eso convertirla en una suerte de intermediaria, obstaculizante de la relación entre Perón y su pueblo."Eva no había interferido en la relación, no la había refractado, porque en definitiva su pasión la había situado muy cerca de Perón, pero también muy cerca del pueblo. Tanto que, de algún modo, se había confundido con ellos". Daniela Slipak, Las revistas montoneras, Buenos Aires, 2015, 89.

${ }^{56}$ Navarro, op. cit., 322.

57 "Presencia de Evita", Trinchera de la Juventud Peronista, 2, 10, 08/1961, 2.
} 
de otro modo, un regreso a los "felices años peronistas"-, Evita simbolizaba el modelo que debía seguir todo joven militante: pasión, fanatismo, obediencia y abnegación total. Asimismo, era precisamente su muerte la prueba de que entre Perón y su pueblo -del que los jóvenes se sentían parte, lógicamente- existía una unión inquebrantable, un sólido vínculo que trascendía fronteras geográficas y temporales. Era, entonces, Evita, "puente de Amor entre el Líder [Perón] y los Descamisados". ${ }^{58}$

\section{Conclusiones}

Preguntarse por los modos en que diversas tradiciones son tomadas y resignificadas por un grupo es el primer paso para cuestionar la posibilidad de pensar tradiciones puras y aisladas. En contra de esta tentativa, en este trabajo se las entendió como una suerte de síntesis, híbridos compuestos por elementos pertenecientes a distintas filiaciones. No existe la posibilidad, en este sentido, de encontrar el grado cero de una tradición determinada. Como una suerte de vitral, las tradiciones son un complejo, contingente y heteróclito conjunto, compuesto por capas sedimentadas de significados, a veces, a simple vista, incompatibles.

Una manera de desandar el cordel de una tradición en particular es asumirla, nada más y nada menos, que como un tipo ideal. Esta función, empero, no debiera obliterar la complejidad que anida en su seno. Este trabajo, nuevamente, parapetándose en las reflexiones pretéritas, trató de "desenrollar" el cordel de la tradición peronista durante los primeros años sesenta, analizando, para ello, el órgano de expresión de la "Mesa Ejecutiva de la Juventud Peronita de la Capital Federal y del Gran Buenos Aires", Trinchera de la Juventud Peronista. Esta semiclandestina y artesanal publicación permite desarrollar un diagnóstico de la agitada y cambiantes situación por la que atravesaba el peronismo en aquellos años; con su movimiento proscripto, sus militantes perseguidos y su líder exiliado.

Aquí se interrogó a Trinchera acerca del modo en que fueron presentados "los años peronistas" y el "17 de Octubre". También, se buscó indagar cuál fue el lugar asignado a Perón, el modo en que concibió la figura de Evita y, por último, de qué forma fue explicado el golpe de Estado de 1955.

Mientras que la principal celebración peronista, el "17 de Octubre", fue concebida como un verdadero momento revolucionario, primer mojón de lo que sería el régimen peronista, símbolo de la reivindicación del pueblo abatido, el golpe del año 55, como contrapartida, representó, para los jóvenes de la "Mesa", el intento más acabado por retornar al estado de cosas anterior al peronism, a los tiempos lejanos a su acontecer; intento, por otro lado, que las medidas económicas y la represión sistemática de la "Revolución Libertadora", y de los gobiernos de Frondizi y Guido respaldaban.

En lo que se refiere a las figuras de Perón y Evita, por un lado, el primero fue erigido como la imagen de un genial estratega que, en la lejanía y en las peripecias de su exilio, no abandonaba la lucha, desarrollando todas las estrategias necesarias para regresar al país. Era, en resumidas cuentas, la encarnación de la razón. Del otro lado, Evita fue

\footnotetext{
58 “Evita”, Trinchera de la Juventud Peronista, 1, 3, 10/1960, 5.
} 
representada como la pasión más desbocada; un modelo que debía guiar a todo joven militante. Evita era, asimismo, el fanatismo, la abnegación total, aún a riesgo de su propia vida, la obediencia a los designios, planes y estratagemas de Perón. Era, incluso, la prueba más palpable, un testimonio innegable, de que Perón y su pueblo tenían un vínculo sólido, una unión inquebrantable, allende tiempos y lugares.

Con la guía estratégica de Perón y del "modelo evitista" de conducta, los jóvenes peronistas de la "Mesa", "reserva moral del Movimiento", se concebían a sí mismos como la encarnación del pueblo, encargados de llevar a cabo el regreso de Perón al país y poner sobre rieles nuevamente la "Revolución nacional peronista", apelando a los medios que sean necesarios, costara lo que costara, "cayera quien cayera".

El trabajo presentado pretendió complejizar la mirada sobre un periodo de la historia del peronismo sólo recientemente estudiado en profundidad en lo que son sus distintas y enmarañadas manifestaciones: los años sesenta. Estás páginas, a través del análisis de los contornos que tomó la heredad peronista en su primera organización juvenil, intentó abonar en este sentido. Se buscó aquí escapar, entonces, de las lecturas que sobre los sesenta han permeado una imensa mayoría de estudios: las que pretendieron encontrar en los fenómenos propios de la década del sesenta, las claves explicativas de lo que fue la violenta radicalización política de la de los setenta. Se trató aquí, en otras palabras, de devolver al fenómeno peronista una espesura que numerosos trabajos han obliterado.

Futuros trabajos, no obstante, deberían ahondar en las manifestaciones que tomó la tradición peronista en los años inmediatamete posteriores al exilio de Perón; sea esto en los sectores de la juventud, en los sindicales o en aquellos más ligados a la estructura partidaria. Asimismo, investigaciones posteriores deberían interrogarse por los modos en que aquella heredad fue procesada al interior de las variopintas organizaciones peronistas en las provincias. Estos y otros interrogantes permitirán un acercamiento al fenómeno peronista en los años sesenta, en gran medida libre de los pesos de los setenta. Estas páginas, en definitiva, procuraron un acercamiento de esta naturaleza.

\section{Bibliografía}

- Aboy Carlés, Gerardo, Las dos fronteras de la democracia argentina, Rosario, Homo Sapiens, 2001.

- Acha, Omar, Los muchachos peronistas. Orígenes olvidados de la Juventud Peronista (19451955), Buenos Aires, Planeta, 2011.

- Anzorena, Oscar, Historia de la Juventud Peronista 1955-1988, Buenos Aires, Del Cordón, 1989.

- Bozza, Juan, "El peronismo revolucionario. Itinerario y vertientes de la radicalización, 19591969”, Sociohistórica, 9, 2001, 135-169.

- Bertolucci, Mónica, "Los hijos peronistas 1955-1966", Segundo Congreso de Estudios sobre el Peronismo (1943 - 1976), Red de Estudios sobre el Peronismo, Universidad Nacional de Tres de Febrero, 2010.

- Carman, Facundo, El poder de la palabra escrita. Revistas y periódicos argentinos (19551976), Buenos Aires, Biblioteca Nacional, 2015. 
- Damin, Nicolás, Plan Conintes y Resistencia Peronista, 1955-1973, Buenos Aires, Instituto Juan Domingo Perón, 2010.

- Deleuze, Giles y Guattari, Felix, Capitalismo y esquizofrenia. Mil Mesetas, Valencia, PreTextos, 2002.

- Ehrlich, Laura, "Los espacios de sociabilidad en la estructuración de la Juventud Peronista post '55 en la Ciudad de Buenos Aires", Apuntes de investigación del CECYP, Buenos Aires, XVI, $21,2012,157-175$.

- $\quad$ "Nacionalismo y arquetipo heroico de la Juventud Peronista a comienzos de la dedicada del 60", Anuario IEHS, 28, 2013, 37-57.

- _ _ _ _Figuras de Eva Perón entre los peronistas en la década del 60", V Congreso de Estudios sobre el Peronismo (1943-2016), Resistencia, 2016. Inédito.

- Gordillo, Mónica, "Protesta, rebelión y movilización: de la resistencia a la lucha armada, 19551973", Daniel James (dir.), Violencia, proscripción y autoritarismo (1955-1973), Buenos Aires, Sudamericana, 2003.

- Gorza, Anabella, "Los homenajes a Eva Perón como prácticas de memoria en tiempos de la Resistencia peronista (1955-1963)", Anuario del Instituto de Historia Argentina, La Plata, 2016, 1-22.

- Hobsbawm, Eric y Ranger, Terence, La invención de la tradición, Barcelona, Crítica, 2002.

- James, Daniel, Resistencia e integración, Sudamericana, 1990.

- Laclau, Ernesto y Mouffe, Chantal, Hegemonía y estrategia socialista, Buenos Aires, FCE, 2010.

- McGuire, James, "Perón y los sindicatos: la lucha por el liderazgo peronista", Samuel Amaral y Mariano Ben Plotkin (comp.), Perón: del exilio al poder, San Martín, Cántaro, 1993.

- Monzó, Florencio (h), Llegó carta de Perón, Buenos Aires, Corregidor, 2006.

- Navarro, Marysa, Evita, Buenos Aires, Edhasa, 2007.

- Palti, Elías, La nación como problema. Los historiadores y la "cuestión nacional", Buenos Aires, FCE, 2002.

- Pontoriero, Esteban, "Estado de excepción y contrainsurgencia: el Plan Conintes y la militarización de la seguridad interna en la Argentina (1958-1962)", Contenciosa, II, N4, 2015, p. 1-13.

- Raimundo, Marcelo, "Compañero y los orígenes del Peronismo Revolucionario", Sociohistórica, 8, 2001, 203-226.

- Renan, Ernest, ¿Qué es la nación?, Buenos Aires, Hydra, 2010.

- Salas, Ernesto, El origen de la guerrilla peronista, Buenos Aires, Biblos, 2003.

- _ La Resistencia Peronista. La toma del frigorífico Lisando de la Torre, Buenos Aires, Altamira, 2006.

- Sarlo, Beatriz, "Eva Perón: algunos temas", Carlos Altamirano (ed.), La Argentina en el siglo XX, Buenos Aires, Ariel, 1999.

- Schneider, Alejandro, Los compañeros, Buenos Aires, Imago Mundi, 2005.

- Slipak, Daniela, Las revistas montoneras, Buenos Aires, 2015.

- Spinelli, María Estela, Los vencedores vencidos. El antiperonismo y la Revolución Libertadora, Buenos Aires, Biblos, 2005.

- Pujol, Sergio, "Rebeldes y modernos. Una cultura de los jóvenes", en Daniel James (dir.), Violencia, proscripción y autoritarismo (1955-1976), Buenos Aires, Sudamericana, 2003, 294.

- Verón, Eliseo y Sigal, Silvia, Perón o muerte, Buenos Aires, Eudeba, 2014. 
- Zaida Lobato, Mirta y Tornay, Lizel, "La política como espectáculo: imágenes del 17 de Octubre”, Santiago Senén Gonzalez y Gabriel D. Lerman (comp.), El 17 de octubre de 1945. Antes durante y después, Buenos Aires, Lumiere, 2005.

\section{Revista}

- Trinchera de la Juventud Peronista, 17 números, octubre de 1960 a junio de 1963. 